\title{
Meteorological Evaluation of Multiple Reactor Contamination Probabilities for a Hanford Nuclear Energy Center
}

by

J. v. Ramsdell

D. I. Diebel

March 1978

Prepared for the

U.S. Department of Energy

under Contract EY-76-C-06-1830

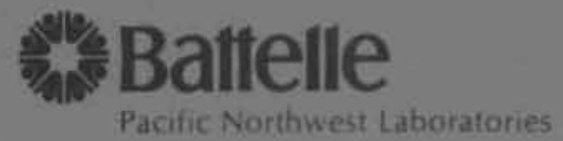


NOTICE

This report was prepared as an account of work sponsored by the United States Government. Neither the United States nor the Department of Energy, nor any of their employees, nor any of their contractors, subcontractors, or their employees, makes any warranty, express or implied, or assumes any legal liability or responsibility for the accuracy, completeness or usefulness of any information, apparatus, product or process Jisclosed, or represents that its use would not infringe privately owned rights.

The views, opinions and conclusions contained in this report are those of the contractor and do not necessarily represent those of the United States Covernment or the United States Department of Energy

\author{
PACIFIC NORTHWEST LABORATORY \\ operated by \\ BATTELLE \\ for the \\ UNITED STATES DEPARTMENT OF ENERGY \\ Under Contract EY-76-C-06-1830
}

\begin{tabular}{|c|c|c|}
\hline \multicolumn{3}{|c|}{$\begin{array}{c}\text { Printed in the United States of Ameri } \\
\text { Available from } \\
\text { National Technical Information Servi } \\
\text { United States Department of Commer } \\
5285 \text { Port Royal Road } \\
\text { Springfield, Virginia 2215T }\end{array}$} \\
\hline ice: & Printed Copy & 5 - Microfiche \\
\hline & "Pages & Selling Price \\
\hline & $001-025$ & 54.50 \\
\hline & $026-050$ & 55.00 \\
\hline & $051-075$ & 55.50 \\
\hline & $075 \cdot 100$ & 56.00 \\
\hline & $101-125$ & Sh. 50 \\
\hline & $126-150$ & 57.00 \\
\hline & $151-175$ & 57.75 \\
\hline & $176-200$ & 58.50 \\
\hline & 201.225 & 59.75 \\
\hline & $226-250$ & 39.00 \\
\hline & $251-275$ & $\$ 10.00$ \\
\hline & $276 \cdot 100$ & 570.25 \\
\hline
\end{tabular}


PNL -2452

UC-80

\section{9}

METEOROLOGICAL EVALUATION OF MULTIPLE REACTOR CONTAMINATION PROBABILITIES

FOR A HANFORD NUCLEAR ENERGY CENTER

J. V. Ramsdell and D. I. Diebel

March 1978

BATTELLE

PACIFIC NORTHWEST LABORATORIES

RICHLAND，WASHINGTON 99352 


\section{CONTENTS}

TABLES. • . • . . . . . . . . . . . . . . . . . . FIGURES • • • • • • • • • • • • • • • • • • • • • • • • V V INTRODUCTION. • • . . . . . . . . . . . . . . . . . 1 THEORETICAL DEVELOPMENT • • • • • • • • • • • • • • • • . 2

Basic Assumptions. . . . . . . . . . . . . . . 3

Development. . . . . . . . . . . . . . . . . 4 THE HANFORD NUCLEAR ENERGY CENTER . . . . . . . . . . . . . 9

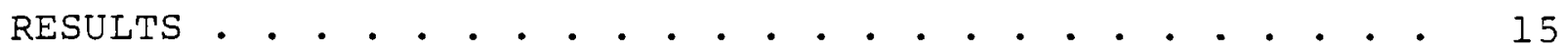

Primary Results. • . • . . . . . . . . . . 16 Model Sensitivity. • • • • • • • • • • • • • . 19

Mixing Height • • • • • • • • • . . . . . . 19

Source and Plume Width. . . . . . . . . . . 20

Energy Center Configuration . . . . . . . . . 24

Cluster Spacing . • . • . . . . . . . . . . 26

Deposition Velocity . • . . . . . • • . . . 29

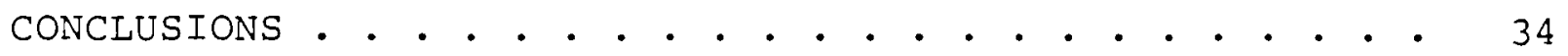

APPENDIX A: Reactor Accident Classes. • . . . • . . • . 37

APPENDIX B: Accidents Involving Reactor Cores . . . . . 39

REFERENCES. • • • • • • • • • • • • • • • • • • • • 442 


\section{TABLES}

Table

1 Make-Up and Position of the HNEC Reactor

clusters . . . . . . . . . . . . . . . .

2 Joint Probability of Wind Direction, Wind

Speed and Atmospheric Stability at 200'

for Hanford. . . . . . . . . . . . . . . . . .

3 Relationship Between Hanford and PasquillGifford Stability Classes and the Determination of Sigma $\mathrm{Z}$. . . . . . . . . . .

4 Conditional Probability That at Least $M$ Reactors would be Contaminated Following an Accident at an HNEC. Contamination Defined by Normalized Air Concentration Equal to or Greater than Tabled Value. . . . . .

5 Conditional Probability that at Least $M$ Reactors would be Contaminated Following an Accident at an HNEC. Contamination Defined by Normalized Surface Concentration Equal to or Greater than Tabled Value. . . . .

Variation of the Conditional probability That at Least $M$ Reactors would be Contaminated Following an Accident at an HNEC with Source and Plume width. Contamination Defined by Air or Surface Concentration Greater than Zero . . . . . . . . . . . . . . . .

7 Variation of Conditional Probability That at Least $M$ Reactors Would be Contaminated Following an Accident at an HNEC with source and Plume Width. Contamination Defined by Normalized Air Concentration Greater than $10^{-7} \mathrm{sm}^{-3}$ or Normalized Surface Concentration Greater than $10^{-9} \mathrm{~m}^{-2}$. . . . . . . . . . . . . . . .

8 Variation of Conditional Probability that at Least $M$ Reactors Would be Contaminated Following an Accident at an HNEC with NEC Geometric Configuration. Contamination Defined by Normalized Air or Surface Concentration Greater than Zero. . . . . . . . . . . • . . 
9 Variation of Conditional Probability That at Least $M$ Reactors Would be Contaminated Following an Accident at an HNEC With configuration and Spacing Between Clusters. Contamination Defined by Normalized Air Concentration Equal to or Greater than $10^{-7} \mathrm{sm}^{-3}$ or Normalized Surface Concentration Equal to or Greater than $10^{-9} \mathrm{~m}^{-2}$. . . . . . . . . . . . . . .

10 Conditional probability That at Least $M$ Reactors Would be Contaminated Following an Accident at an HNEC, Assuming Close Spacing. Contamination Defined by Normalized Air Concentration Equal to or Greater than Tabled value . . . . . . . . . . . . • . . . 28

Al Classification of Postulated Accidents and Occurrences . . . . . . . . . . . . • . . . . 38

B1 Release Categories Following Reactor Accidents Involving Core. . . . . . . . . . . 40

B2 Parameters of Releases Following Reactor Accidents Involving Core. . . . . . . . . . . 


\section{FIGURES}

\section{Figure}

Potential HNEC Cluster Locations. . . . . . 10

Plume Source and Receptor Geometry. • . . . 12

Variation of Conditional Probability That 7 or More Reactors Would be Contaminated Following an Accident in an HNEC With Deposition Velocity. Contamination Defined by Normalized Air Concentration . . . . . 30

4 Variation of Conditional Probability That 11 or More Reactors Would be Contaminated Following an Accident in an HNEC With Deposition Velocity. Contamination Defined by Normalized Air Concentration . . . . . • 31

5 Variation of Conditional Probability That 7 or More Reactors Would be Contaminated Following an Accident in an HNEC With

Deposition Velocity. Contamination Defined by Normalized Surface Concentration . . . . 32

6 Variation of Conditional Probability That 11 or More Reactors Would be Contaminated Following an Accident in an HNEC With Deposition Velocity. Contamination Defined by Normalized Surface Concentration . . . . 
, . 


\section{METEOROLOGICAL EVALUATION \\ OF MULTIPLE REACTOR CONTAMINATION PROBABILITIES \\ FOR A HANFORD NUCLEAR ENERGY CENTER}

J. V. Ramsdell and D. I. Diebel

\section{INTRODUCTION}

One alternative in the siting of power plants is the energy center, where 10 to 40 power plants are located at a common site. Within the energy center the individual generating units are generally grouped in clusters of about 4. The Pacific Northwest Laboratory has been studying the application of this concept to the Department of Energy's Hanford area for several years ${ }^{(1-3)}$. The conceptual Hanford energy center is composed of nuclear power plants, hence the name Hanford Nuclear Energy Center (HNEC). Previous topical reports have covered a variety of subjects related to the HNEC including: electric power transmission (4), fuel cycle ${ }^{(5)}$, and heat disposal ${ }^{(6-8)}$. This report discusses the probability that a radiation release from a single reactor in the HNEC would contaminate other facilities in the center. The risks, in terms of reliability of generation, of this potential contamination are examined by Clark and Dowis (9).

The grouping of power generating facilities increases the possibility that several, or all, of the facilities might be disabled by a single event. If the energy center contains a nuclear power plant, a reactor accident could lead to the shutdown of other units. Significant reactor accidents are highly improbable, but could result from the successive failure of reactor safety features. These are discussed in References (10) and (11)*. Significant releases of radioactivity could also occur from a nuclear fuels reprocessing plant, however releases from reprocessing plants have not been considered in this analysis.

*Appendix A contains a description of the various classes of reactor accidents, and Appendix $B$ describes reactor accidents involving reactor cores. 
To evaluate the risks associated with multiple reactor contamination following a release of radioactivity, it is necessary to estimate the probability that more than 1 reactor or cluster will be contaminated at some level as well as estimate the probability of an accident at a single reactor. Reference (11) and Appendix B provide information needed to estimate the probability of an accident in a single reactor. This report concentrates on the estimation of the probability of multiple reactor contamination assuming that a release will occur.

The following section presents an outline of the theoretical problem and its solution. It is followed by a description of the Hanford Nuclear Energy Center and its climatology. The results of the study are then presented and sensitivity of the results to changes in variables is explored. Finally conclusions drawn from the work are summarized.

\section{THEORETICAL DEVELOPMENT}

In case of a reactor accident involving a significant release of activity in an energy center, the multiple reactor contamination problem resolves into two types of questions. The first deals with determination of the number of reactors directly downwind of the accident, and the second deals with the concentration of material in the plume or deposited on exposed surfaces in the vicinity of each reactor downwind of the accident.

once the locations of reactors in an energy center are specified, the number of reactors directly downwind of an accident is determined by the location of the accident, the wind direction, and the plume width. The contamination at each reactor in the plume is determined by its distance from the accident, the amount of material released and variables that control the diffusion and deposition of atmospheric contaminants, such as wind speed, stability and mixing depth. Thus, the probability 
needed in risk assessment must be specified in terms of number of power plants and level of contamination. In this section, a general method will be developed for making estimates of this bivariate probability.

\section{Basic Assumptions}

As estimating the required probability depends on numerous assumptions, the validity of the estimates are no better than the underlying assumptions. Therefore, basic assumptions made in the development of the general method of solution are stated explicitly here.

It is postulated that significant accidents are equally probable in all nuclear power plants in an energy center, and further that the probability of two accidents occurring simultaneously is negligible. This leads directly to the assumption that the probability of a significant accident in a nuclear energy center is:

$$
P_{A}=N_{t} P(1)
$$

Where $P_{A}$ is the probability of an accident in the center, $P(1)$ is the probability of an accident in any given reactor and $N_{t}$ is the total number of reactors. Determination of $P(1)$ is the province of reactor design and safety engineers, therefore $P(I)$ will be assumed to be known. The probability $P(M, I)$ of $M$ power plants being contaminated at a level $I$ is given by

$$
P(M, I)=P(M, I \mid A) P_{A}
$$

where $P(M, I \mid A)$ is a conditional probability assuming that an accident will occur. This conditional probability is a function of energy center geometry and climate. 
Theoretically, the conditional probability can be determined by considering all permutations and combinations of individual reactors, discarding those which cannot occur for geometric reasons, and weighting the possible combinations by the frequency of occurrence of wind direction, wind speed and atmospheric stability. However, as the $\mathrm{N}_{t}$ increases, this procedure rapidly becomes impractical because the number of permutations which must be evaluated is proportional to $\mathrm{N}_{t}$ ! To reduce the number of combinations, it has been assumed that the power plants in a cluster may be treated together; if one reactor in a cluster is contaminated following an accident, all are. The conditional probability that an accident will occur in a given cluster, $P_{S} \mid A^{\prime}$ is

$$
P_{s \mid A}=\frac{n_{s}}{N_{t}}
$$

where $\mathrm{n}_{\mathrm{s}}$ is the number of reactors in the cluster, again assuming that an accident will occur in the energy center.

Development

If an accident occurs in a given reactor in an energy center under known atmospheric conditions, standard diffusion models can be used to determine the number of downwind clusters, and to estimate the concentration of radioactive materials in the air and deposited on the surface at each cluster. As the distance from the release point increases the number of clusters potentially involved will increase, but the concentration in the plume and on the surface will decrease. Thus, to define the number of reactors significantly affected following an accidental release it is necessary to first define a minimum significant contamination level. 
The atmospheric diffusion of non-depositing materials has been studied extensively, and currently accepted models are described in standard reference works $(12,13)$. A general sectoraverage model has been developed for diffusion computations with respect to the $\mathrm{HNEC}^{(8)}$. This model is:

$$
\begin{aligned}
(\bar{x} / \dot{Q}) & =\frac{\hat{n}}{(2 \pi)^{3 / 2} \sigma_{z} \overline{\mathrm{u} x}} \sum_{j=-\infty}^{\infty}\left\{\exp \left[\frac{(z-h+2 j H)^{2}}{-2 \sigma_{z}^{2}}\right]\right. \\
& \left.+\exp \left[\frac{(z+h+2 j H)^{2}}{-2 \sigma_{z}^{2}}\right]\right\}
\end{aligned}
$$

where:

$(\bar{x} / \dot{Q})$ is the average air concentration at a distance $x$ from the source and a height $z$ above ground divided by the release rate $\dot{Q}$.

$\hat{n}$ is related to the assumed plume width, $\phi_{0}$, by $\hat{n}=\pi / \phi_{0}$ when $\phi_{0}$ is in radians.

$\sigma_{z}$ is a vertical diffusion parameter related to atmospheric stability.

$\overrightarrow{\mathrm{u}}$ is the wind speed.

$\mathrm{h}$ is the effective release height, and

$\mathrm{H}$ is the height of the mixed layer.

In the present context both $\mathrm{z}$ and $\mathrm{h}$ can be assumed to be zero, and Equation (4) simplifies to:

$$
\left(\frac{\bar{x}}{\dot{Q}}\right)=\frac{2 \hat{n}}{(2 \pi)^{3 / 2} \sigma_{z} \overline{u x}}\left[I+2 \sum_{j=1}^{\infty} \exp \left(\frac{-2 j^{2} H^{2}}{\sigma_{z}^{2}}\right)\right] \text {. }
$$


And, as a practical matter the infinite sum can be truncated after $j=2$ without significant effect.

As the material released during an accident is carried downwind, it will deposit on surfaces. Since the deposited material is no longer in the plume, air concentrations should be reduced from the values computed using Equation (5). Van der Hoven (14) describes the correction that is usually made. In that correction, the source term becomes a function of distance, and is reduced as distance increases,

$$
\dot{Q}(x)=\dot{Q}_{0} \exp \left\{-\frac{2}{\sqrt{2 \pi} \bar{u}} \int_{0}^{x} \frac{V_{d}}{\sigma_{z}} d \xi\right\}
$$

$Q(x)$ is the depleted source term, $\dot{Q}_{0}$ is the initial source term, and $V_{d}$ is the ratio between the flux of material to the surface and the air concentration near the surface. This correction, in effect, depletes material from the whole plume. A more realistic correction model (15) depletes the material at the surface and diffuses a concentration deficit vertically. The two corrections have been compared by Horst ${ }^{(15)}$. On the basis of this comparison, the source depletion model was determined to be adequate for the current study.

Incorporating the deposition correction, the air concentration at the surface for a depositing material is given by:

$$
\left(\bar{x} / \dot{Q}_{0}\right)=\left(\frac{\bar{x}}{\dot{Q}(x)}\right) \exp \left\{\frac{-2}{\sqrt{2 \pi} \bar{u}} \int_{x_{1}}^{x_{2}} \frac{V_{d}}{\sigma_{z}} d \xi\right\}
$$

where $x_{1}$ is the distance from the virtual to real source and $\mathrm{x}_{2}$ is the distance from the virtual source to the receptor. By definition the amount of material deposited is: 


$$
\left(\frac{\omega}{\bar{Q}_{0}}\right)=v_{\mathrm{d}}\left(\frac{\bar{x}}{\dot{Q}_{0}}\right)
$$

where $\omega$ is the surface concentration in $\mathrm{gm}^{-2}$ and $Q_{0}=\dot{Q}_{0} T$. $T$ is the duration of plume passage (assumed to be equal to the release duration).

Contamination following an accident is now defined by Equations (7) and (8). Clearly there are two conditional probabilities of interest, one with contamination defined in terms of $\left(\bar{x} / \dot{Q}_{0}\right)$ and the other defined in terms of $\left(\omega / Q_{0}\right)$. The first will be denoted by $P_{1}(M, I \mid A)$ and the second by $P_{2}(M, J \mid A)$.

Since $\left(\bar{x} / \dot{Q}_{0}\right)$ and $\left(\omega / Q_{0}\right)$ are continuous variables it is necessary to establish ranges of involvement before the conditional probabilities are defined. If, for $\left(\bar{x} / \dot{O}_{0}\right)$ the range limits are denoted by $a_{i}, i \geq 1$, and for $\left(\omega / Q_{0}\right)$ they are denoted by $b_{j}, j \geq 1$, then we let

$$
I=i \text { for } a_{i} \leq\left(\frac{\bar{x}}{\bar{Q}_{0}}\right)<a_{i+1}
$$

and

$$
J=j \text { for } b_{j} \leq\left(\frac{\omega}{Q_{0}}\right)<b_{j+1}
$$

The number of power plants involved is equal to the total number of power plants in the source cluster and in downwind receptor clusters with $I$ and/or $J$ greater than some predetermined value.

If there are several clusters downwind of a release there will be several pairs of $M$ and $I$ or $J$ for which probabilities can be estimated. The first pairs will be $M=M_{0}=n_{s}$, where $n_{s}$ is again the number of reactors in the source cluster, and $I$, $\mathrm{J}=$ maximum values. In the second, $\mathrm{M}=\mathrm{M}_{1}=\mathrm{n}_{\mathrm{s}}+\mathrm{n}_{1}$ where $\mathrm{n}_{1}$ is 
number of power plants in the closest receptor cluster. This value of $M$ will be paired with values of $I$ and $J$ determined for the receptor cluster. If there is a second receptor cluster, a third set of pairs will have $M=n_{s}+n_{1}+n_{2}$, and $I$ and $J$ determined for the second receptor cluster. The existence of $\mathrm{m}_{2}$ implies the existence of $m_{1}$ and $m_{0}$ where $m_{2}>m_{1}>m_{0}$. It also implies the existence of higher degrees of contamination for $m_{1}$ and $m_{0}$.

Given a source cluster, wind direction, wind speed, atmospheric stability and receptor cluster locations, values for $M, I$ and $J$ can now be computed. Computation of conditional probabilities associated with the given conditions requires the frequency of occurrence of the given meteorological conditions. Denoting that frequency by $f(\theta, u, s t)$, where $\theta$ represents wind direction, $u$ represents wind speed and st represents atmospheric stability, the conditional probability for each pair of values is given by the product

$$
P_{s \mid A} f(\theta, u, s t)
$$

For the energy center the conditional probabilities are estimated by summing over all sources and atmospheric conditions. Thus,

$$
P_{l}(M, I \mid A)=\sum_{s} \sum_{\theta} \sum_{u} \sum_{s t} P_{s \mid A} E(\theta, u, s t)
$$

and

$$
P_{2}(M, J \mid A)=\sum_{s} \sum_{\theta} \sum_{u} \sum_{s t} P_{s} \mid A f(\theta, u, s t)
$$

where $M, I$ and $J$ are determined as before. Equations (10a) and (lOb) are not the final forms on which the HNEC analysis was based. Rather the analysis was based on the cumulative 
probabilities that at least $k$ power plants would be contaminated at level $\ell$ or greater. These cumulative probabilities result from the summations

$$
\begin{aligned}
& P_{1}^{*}(M, I \mid A)=\sum_{M=k}^{N_{t}} \sum_{I=l}^{\ell} P_{1}(M, I A) \\
& P_{2}^{*}(M, J \mid A)=\sum_{M=k}^{N_{t}} \sum_{J=l}^{l} P_{2}\left(\begin{array}{ll}
M, J x & A
\end{array}\right)
\end{aligned}
$$

The astrisks are used to indicate the double summation where these conditional probabilities are discussed in the remainder of the report.

THE HANFORD NUCLEAR ENERGY CENTER

During the HNEC conceptual studies numerous sites have been considered as potential cluster locations. Figure 1 shows the boundaries of the Hanford area and 14 of the locations considered. Analysis of the HNEC concept is currently concentrating on a 20 power plant center with clusters located at sites 1 through 5 . In this report, HNEC specifically refers to power plant clusters at these locations. Table 1 gives the make-up of each cluster and its position in the computational grid.

In the computational scheme, the reactors within a cluster are treated as a single entity; no effort has been made to examine intra-cluster variations. When a cluster is assumed to contain the reactor that is the release source, the cluster is represented by a structure located at the cluster position which has dimensions typical of power reactors. The horizontal dimension assumed is $100 \mathrm{~m}$, and the vertical is $61 \mathrm{~m}$. When a cluster is considered as a potential receptor following release in another cluster, it is represented simply by a point. 


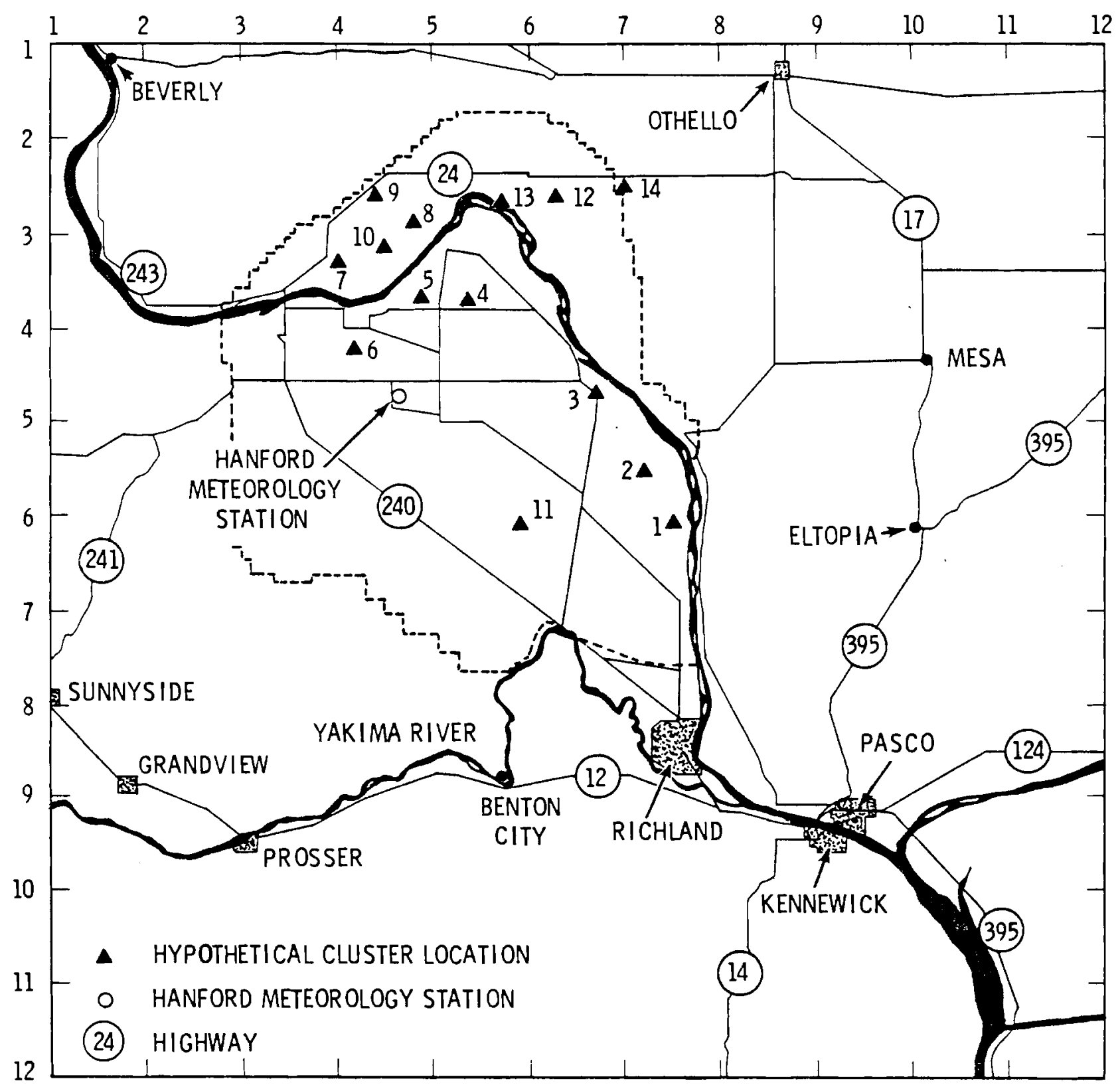

FIGURE 1. Potential HNEC Cluster Locations. 


\section{TABLE 1. Make-Up and Position of the HNEC Reactor Clusters}

\begin{tabular}{|c|c|c|c|}
\hline Cluster & $\begin{array}{l}\text { Number } \\
\text { of Reactors }\end{array}$ & $\begin{array}{l}\text { Grid } \\
M-S\end{array}$ & $\begin{array}{r}\text { Position } \\
E-W\end{array}$ \\
\hline 1 & 5 & 6.10 & 7.50 \\
\hline 2 & 4 & 5.50 & 7.20 \\
\hline 3 & 4 & 4.70 & 6.70 \\
\hline 4 & 3 & 3.70 & 5.40 \\
\hline 5 & 4 & 3.70 & 4.90 \\
\hline
\end{tabular}

The source-receptor geometry is shown in Figure 2. The source cluster is located at point $A$ with its horizontal dimension perpendicular to the wind direction. The sensitivity of results to variations in model parameters, including source width, will be examined in a later section. The receptor cluster is located at point $C$. Because the diffusion model used (Equation 5) is for point sources and the actual source is assumed to have a finite width, it is necessary to determine a virtual point source, B. Points $A$ and $C$ are determined when the physical configuration of the energy center is established, but point B must be determined relative to $A$ from the source width, the wind direction and the angular width of the plume. Determination of whether or not a particular receptor is in a particular plume is described in Reference 8.

In addition to characterizing the HNEC by its physical dimensions, it is necessary to characterize it climatologically. The basic reference on Hanford Climatology is Climatography of the Hanford Area (16). Additional information relative to the conceptual HNEC is given in Reference 8. In general, the climate is typical of a mid-latitude desert-steppe. The prevailing wind directions are northwest and southwest, with 


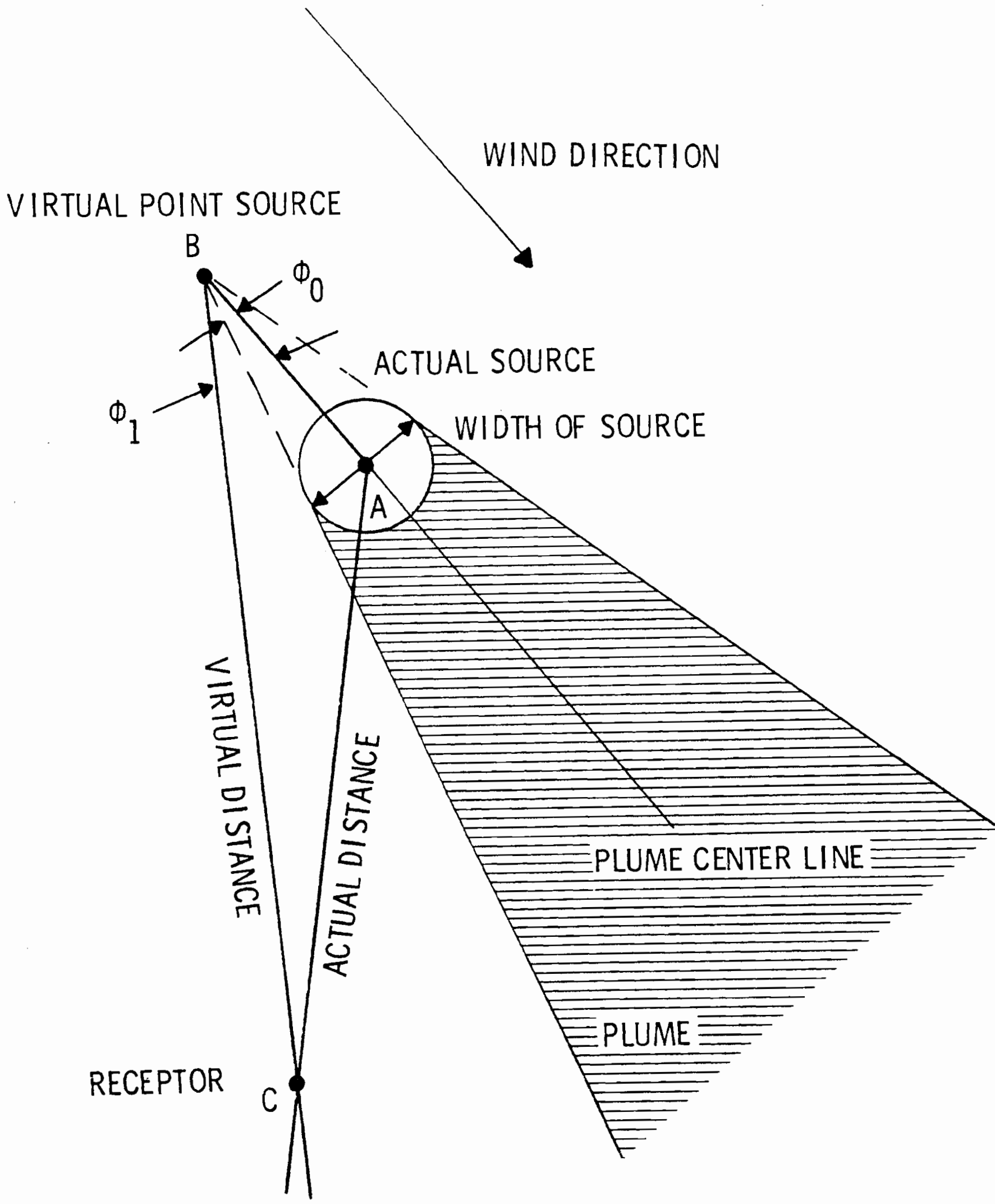

FIGURE 2. Plume Source and Receptor Geometry. 
speeds averaging between 2 and $3 \mathrm{~ms}^{-1}$. However, despite the relatively low averages, there are occasional periods with high speeds.

Atmospheric diffusion is related to wind and atmospheric stability as shown in Equations (4) and (5). A joint frequency distribution of wind direction, wind speed and atmospheric stability is required for diffusion computations involving specific sources and receptors. Table 2 gives this distribution for Hanford. The relationship between Hanford atmospheric stability classes and the more familiar Pasquili-Gifford classes is given in Table 3 . This table also gives the specific relationships used to compute $\sigma_{z}$ as a function of stability and distance from the source. These relationships were developed by Briggs (17).

Examination of the models described in the previous section shows that several additional meteorological parameters must be specified. These are: the plume width, the height of the mixing layer, and the deposition velocity for depositing material.

Selection of the angular width for the sector-average plume model is governed by the form of available wind direction information and the assumed duration of releases of interest. The compilation of the joint frequency wind data in Table 2 , strongly suggests that a minimum sector width of 22.5 be used. This choice is further recommended when the requirements of various Regulatory Guides issued by the Nuclear Regulatory Commission are considered $(18,19)$.

The mixing height tends to vary both daily and seasonally. The greatest mixing heights are generally found on the summer afternoons and the lowest on winter nights. However, for computational purposes a constant value of $1500 \mathrm{~m}$ has been assumed for this study. This value is probably low for summer and high for winter. 
TABLE 2. Joint Probability of Wind Direction, wind speed and Atmospheric Stability at $200^{\prime}$ for Hanford

NRE NE ENE E ESE SE SSE . S SSW SW .WSW W...WW NW NAW N VAR. TALM TOTAL

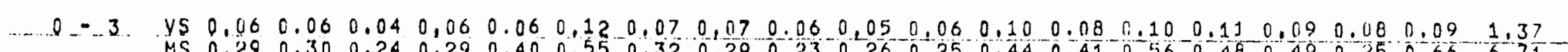
MS $0.290 .30 \quad 0.240 .290 .40 \quad 0.550 .320 .290 .230 .26 \quad 0.250 .440 .410 .56 \quad 0.480 .490 .250 .66 \quad 6.31$

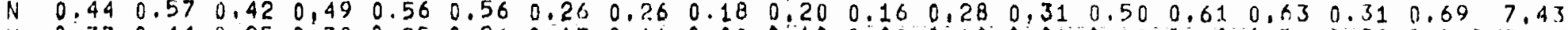
$\begin{array}{lllllllllllllllllllllll} & 0.37 & 0.44 & 0.25 & 0.30 & 0.25 & 0.26 & 0.13 & 0.11 & 0.08 & 0.10 & 0.08 & 0.10 & 0.09 & 0.19 & 0.22 & 0.38 & 0.30 & 0.06 & 3.71\end{array}$

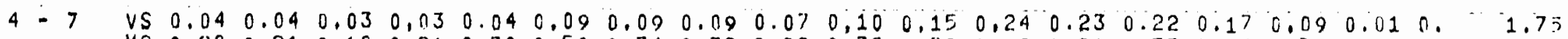

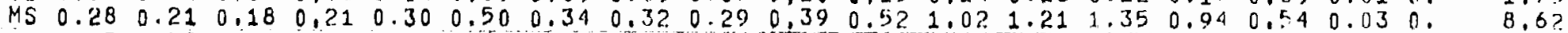

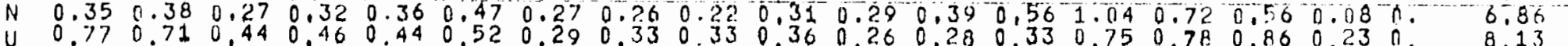

$\begin{array}{lllllllllllllllllllllllll}8-12 \text { VS } & 0.01 & 0.00 & 0.00 & 0.00 & 0.00 & 0.03 & 0.06 & 0.03 & 0.02 & 0.05 & 0.12 & 0.26 & 0.34 & 0.59 & 0.20 & 0.02 & 0.0 & 0 . & 1.74\end{array}$

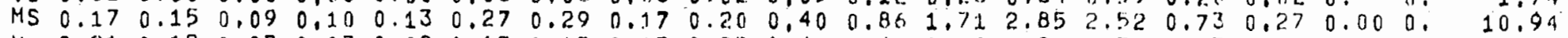

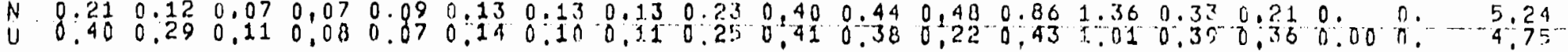

$13-18$

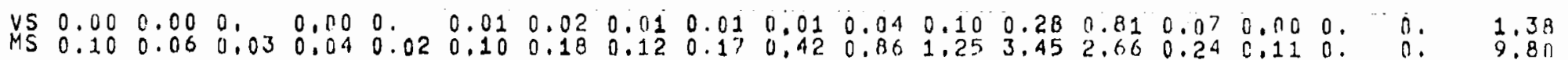

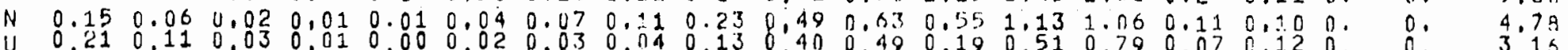

$19-24$

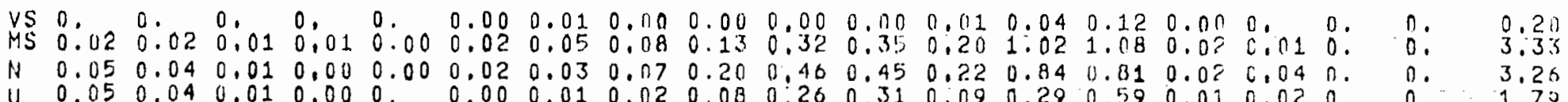

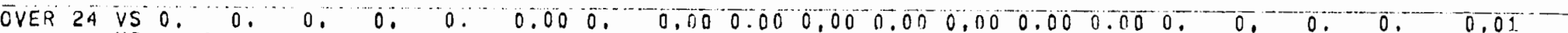

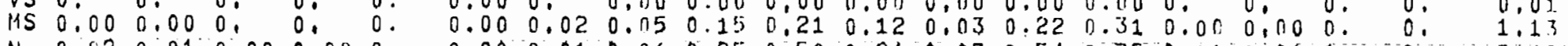

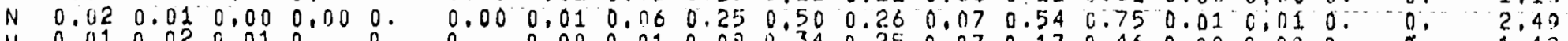

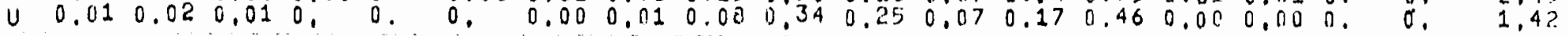

$\begin{array}{clllllllllllllllllllll}\text { TOTALS VS } & 0.11 & 0.11 & 0.07 & 0.10 & 0.11 & 0.25 & 0.24 & 0.20 & 0.16 & 0.22 & 0.39 & 0.71 & 0.96 & 1.85 & 0.56 & 0.70 & 0.09 & 0.09 & 6.44\end{array}$ MS 0.870 .750 .550 .650 .851 .441 .201 .021 .179 .012 .964 .659 .168 .492 .4191 .420 .780 .6640 .53

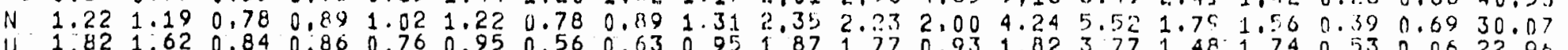


TABLE 3. Relationship Between Hanford and PasquiliGifford Stability Classes and Determination of Sigma $z$

Hanford

Unstable

Neutral

slightly stable

Moderately stable
PasquiliGifford

$\mathrm{B}$

$\mathrm{D}$

$\mathrm{E}$

F $\sigma_{z}$

$.12 \mathrm{x}$

$.06 x /(1+.0015 x)^{1 / 2}$

$.03 x /(1+.0003 x)$

$.02 x /(1+.0003 x)$

The deposition velocity is a function of the density of material, the size of particles (if a particulate), atmospheric turbulence characteristics, and height of reference concentration(20). Many observed values of deposition velocity for materials of interest tend to be about $0.01 \mathrm{~ms}^{-1(14-21)}$. As a result, it is reasonable to assume a constant value of $0.01 \mathrm{~ms}^{-1}$ and accept the accompanying uncertainty in the computations. A more sophisticated treatment of deposition velocity would probably not yield significantly better results with respect to the basic problem under consideration.

Although constant values have been assumed for many of the geometric and meteorological parameters for the primary evaluation of the probability of multiple reactor involvement, the sensitivity of the results to variations in these parameters has been examined. The results of the sensitivity studies are presented in the next section following presentation of the primary study results. In general the primary results are relatively insensitive to small changes in any of the model parameters.

\section{RESULTS}

The results of this study are presented in two sections. The first section presents the primary results, $i . e .$, the values of $P_{I}^{*}(M, J \mid A)$ and $P_{2}^{*}(M, J \mid A)$ computed with Equations (1la) and 
(11b). The second section presents the results of the sensitivity studies.

Primary Results

The primary results of the probability computations are presented in Tables 4 and 5 for ground level air and surface contamination, respectively. It is immediately obvious that the tables are identical except for the definition of contamination and the order of magnitude of the concentration. The reason for this lies in the relationship expressed in Equation (8). However, it is important to remember that the deposition velocity affects the air concentration as well as the surface concentration (Equation (7)).

The probability that more than a single reactor cluster will be contaminated at some level following a release of radioactivity in the HNEC is .194. This is seen in Tables 4 and 5 for $I$ or $J \geq 0$ and $M \geq 7$. Similarly the probability of involvement of 3 or more clusters is .108. These probabilities should be evaluated relative to the conditional probability that a given reactor will be the source of the release, which is .05 .

If an air or surface concentration of significance is identified and a source term is estimated, Tables 4 and 5 can be used to estimate the probability that $M$ or more reactors will be involved at the significant level or at a greater level. Assuming that the ratio between a significant air concentration and release rate is $10^{-7} \mathrm{sm}^{-3}$, Table 4 shows that the probability of 5 or more reactors being involved is .397. The probability of 7 or more being involved is .158, and the probability of 13 or more is .056. Table 5 can be used in a similar manner when a significant surface concentration is defined and the total release is estimated.

If, for some reason, the probability that exactly $y$ clusters will be contaminated is of interest, it can be computed 
TABLE 4. Conditional Probability That at Least $M$ Reactors Would be Contaminated Following an Accident at an HNEC. Contamination Defined by Normalized Air Concentration Equal to or Greater than Tabled Value

Normalized Concentration $\left(\mathrm{sm}^{-3}\right)$

$1.00 \times 10^{-5}$

$4.64 \times 10^{-6}$

$2.15 \times 10^{-6}$

$1.00 \times 10^{-6}$

$4.64 \times 10^{-7}$

$2.15 \times 10^{-7}$

$1.00 \times 10^{-7}$

$4.64 \times 10^{-8}$

$2.15 \times 10^{-8}$

$1.00 \times 10^{-8}$

$>0$
Nhmber of Reactors

\begin{tabular}{llllllllll}
3 & 4 & 5 & 7 & 8 & 9 & 11 & 12 & 13 & 16 \\
\hline
\end{tabular}

$1.000 \quad .850 \quad .250$

$1.000 \quad .852 \quad .256 \quad .006$

$\begin{array}{llllll}1.000 & .853 & .268 & .021 & .008 & .008\end{array}$

$\begin{array}{llllll}1.000 & .853 & .290 & .046 & .028 & .016\end{array}$

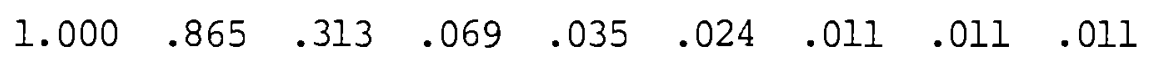

$\begin{array}{lllllllll}1.000 & .876 & .369 & .126 & .088 & .044 & .030 & .016 & .016\end{array}$

$\begin{array}{llllllllll}1.000 & .878 & .397 & .158 & .127 & .081 & .066 & .059 & .056 & .018\end{array}$

$\begin{array}{llllllllll}1.000 & .881 & .409 & .172 & .138 & .098 & .085 & .079 & .073 & .023\end{array}$

$\begin{array}{llllllllll}1.000 & .884 & .417 & .182 & .148 & .102 & .090 & .082 & .075 & .024\end{array}$

$\begin{array}{llllllllll}1.000 & .884 & .421 & .188 & .155 & .108 & .095 & .086 & .078 & .025\end{array}$

$\begin{array}{llllllllll}1.000 & .884 & .427 & .194 & .165 & .121 & .108 & .100 & .090 & .030\end{array}$ 
TABLE 5. Conditional Probability That at Least $M$ Reactors would be Contaminated Following an Accident at an HNEC. Contamination Defined by Normalized Surface Concentration Equal to or Greater than Tabled Value

Normalized concentration $\left(\mathrm{m}^{-2}\right)$

$1.00 \times 10^{-7} \quad 1.000 \quad .850 \quad .250$

$4.64 \times 10^{-8} \quad 1.000 \quad .852 \quad .256 \quad .006$

$\begin{array}{lllllll}2.15 \times 10^{-8} & 1.000 & .853 & .268 & .021 & .008 & .008\end{array}$

$\begin{array}{lllllll}1.00 \times 10^{-8} & 1.000 & .853 & .290 & .046 & .028 & .016\end{array}$

$\begin{array}{lllllllllll}4.64 \times 10^{-9} & 1.000 & .865 & .313 & .069 & .035 & .024 & .011 & .011 & .011\end{array}$

$\begin{array}{lllllllllll}2.15 \times 10^{-9} & 1.000 & .876 & .369 & .126 & .088 & .044 & .030 & .016 & .016\end{array}$

$\begin{array}{lllllllllllll}1.00 \times 10^{-9} & 1.000 & .878 & .397 & .158 & .127 & .081 & .066 & .059 & .056 & .018\end{array}$

$\begin{array}{llllllllllll}4.64 \times 10^{-10} & 1.000 & .881 & .409 & .172 & .138 & .098 & .085 & .079 & .073 & .023\end{array}$

$\begin{array}{llllllllllll}2.15 \times 10^{-10} & 1.000 & .884 & .417 & .182 & .148 & .102 & .090 & .082 & .075 & .024\end{array}$

$\begin{array}{lllllllllllll}1.00 \times 10^{-10} & 1.000 & .884 & .421 & .188 & .155 & .108 & .095 & .086 & .078 & .025\end{array}$

$\begin{array}{llllllllllll}>0 & 1.000 & .884 & .427 & .194 & .165 & .121 & .108 & .100 & .090 & .030\end{array}$ 
from the information in Tables 4 and 5 . This probability is equal to the probability that $y$ or more clusters will be contaminated minus the probability that $y+1$ or more clusters will be. For example, the probability that exactly 2 clusters in an HNEC would be contaminated following a radioactive release is $.194-.108=.086$.

Appendix B provides information for estimating source terms for each release category for several radio-nuclides. Significant air and surface concentrations can be determined in relation to dose rates.

Model Sensitivity

In the preceeding section the tables presented give the conditional probabilities that at least $M$ reactors will be involved at or greater than a given level assuming that a release takes place. A number of assumptions with respect to model parameters were required in the computations that produced the estimates. In this section we examine the effects of varying the parameters. The HNEC case described earlier will serve as a basis for comparison.

The effects of variation of the parameters on air and surface concentrations can be identified by examining Equations (5) through (8). However, our primary interest is in probabilities, air and surface concentrations are only part of the problem. The summations indicated in Equations (10) and (11) tend to mask many of the changes that might be expected on the basis of considering concentrations. In other cases the effects are as expected but somewhat more diffused.

Mixing Height. When probability computations were made for assumed mixing heights of 500,1500 and $2500 \mathrm{~m}$, the resulting variations in probability estimates were judged to be insignificant. Decreasing the height to $500 \mathrm{~m}$ or increasing it to $2500 \mathrm{~m}$ caused changes in probability of less than .01 from the 
values in Tables 4 and 5 . In most cases the changes were .001 or .002 .

Source and Plume width. Intuitively, increasing either the plume or source width can be expected to decrease concentrations at any given distance from the source. Increasing the source width increases the distance from the virtual point source to the real source and the receptor. Equation (5) shows that this decreases the uncorrected air concentration. However when the correction for deposition is considered in Equation (7), the relative increase in the distance to the real source is more than that to the receptor. As a result the value of the integral in the exponential term is reduced and the exponential term approaches unity. This serves to counter the reduction of the uncorrected concentration when the actual air and surface concentrations are estimated. The net effect of increasing the source width may be either an increase or decrease in concentrations.

The effect on the conditional probabilities of increasing source and plume width are shown in Table 6. For both 22.5 and 45 degree plume widths, increasing the source width from 100 to $400 \mathrm{~m}$ has no apparent effect on the probability. Increasing the source width to 1600, with a 22.5 degree plume, increases the probability that two or more clusters will be contaminated by about $7 \%$ and probability of involvement of 3 or more clusters by about $37 \%$. With a $45^{\circ}$ plume, increasing the source width to $1600 \mathrm{~m}$ increases the probability of contamination of 2 or more clusters by less than $2 \%$, and does not affect the probability that 3 or more clusters will be involved. An increase in plume width from $22.5^{\circ}$ to $45^{\circ}$ results in a significant increase in conditional contamination probabilities. For either a 100 or $400 \mathrm{~m}$ wide source the maximum increase in probability is just under $18 \%$ for $M \geq 9$. For an assumed source width of $1600 \mathrm{~m}$, the maximum increase is about $12.5 \%$ for $M \geq 9$. 
TABLE 6. Variation of the Conditional Probability That

at Least $M$ Reactors Would be Contaminated Following an Accident at an HNEC with source and Plume width. Contamination Defined by Air or Surface Concentration Greater than zero

\begin{tabular}{|c|c|c|c|c|c|c|c|c|c|c|c|c|c|c|}
\hline \multirow{2}{*}{$\begin{array}{l}\text { Source } \\
\text { Width } \\
\text { (m) }\end{array}$} & \multirow{2}{*}{$\begin{array}{l}\text { Plume } \\
\text { Width } \\
\left({ }^{\circ}\right) \\
\end{array}$} & \multicolumn{13}{|c|}{$\underline{M}$} \\
\hline & & 3 & 4 & 5 & 7 & 8 & 9 & 11 & 12 & 13 & 15 & 16 & 17 & 20 \\
\hline 100 & $22-1 / 2$ & 1.000 & .884 & .427 & .194 & .165 & .121 & .108 & .100 & .090 & .030 & .030 & & \\
\hline 400 & $22-1 / 2$ & 1.000 & .884 & .427 & .194 & .165 & .121 & .108 & .100 & .090 & .030 & .030 & & \\
\hline 1600 & $22-1 / 2$ & 1.000 & .892 & .529 & .297 & .245 & .193 & .141 & .108 & .108 & .048 & .040 & & \\
\hline 100 & 45 & 1.000 & .926 & .569 & .344 & .300 & .300 & .240 & .190 & .181 & .128 & .120 & .083 & .043 \\
\hline 400 & 45 & 1.000 & .926 & .569 & .344 & .300 & .300 & .240 & .190 & .181 & .128 & .120 & .083 & .043 \\
\hline 1600 & 45 & 1.000 & .926 & .580 & .362 & .318 & .318 & .240 & .190 & .181 & .128 & .120 & .083 & .043 \\
\hline
\end{tabular}


Table 6 is concerned only with the probability that reactors will be in the plume following an accident. It is not concerned with the concentration of material in the plume or on the ground at the reactors. The effects of changes in source and plume width on both plume coverage and concentration are shown in Table 7 for a relatively high level of involvement. The concentration intervals in the computation used prevent a detailed evaluation of the effect on concentration, but trends are evident in the Table.

Assuming a basic plume width of $22.5^{\circ}$, an increase in the source width from 100 to $400 \mathrm{~m}$ slightly increases the probability of 7 or more reactor involvements as seen in Table 7 . Since Table 6 does not show an increase in involvement, the increases in Table 7 must result from increases in concentration due to reduction in deposition near the source. Further increasing the source width to $1600 \mathrm{~m}$ continues to increase the probability of 2 or more clusters being involved, but the increases are less than those due to the increased plume coverage. As a result' they cannot be attributed to increased concentrations. The only exception to this is for $M \geq 5$, where the increase is .093 greater than that due to increased plume coverage.

For a plume width of $45^{\circ}$, Table 7 indicates that increases in source width from 100 to 400 and $1600 \mathrm{~m}$ are accompanied by small changes in probability. When $M$ is greater than 9 the increases must be attributed, in part, to increases in concentration. Changes in probability due to increases in source width are generally less than $1 \%$ for a $45^{\circ}$ wide plume.

Increasing plume width from 22.5 to 45 degrees increases the area covered by the plume by a factor of 2 . However, it also reduces the distance between the virtual and real source. The net effect is an increase in probability that is less than would occur if only the areal increase were considered. 
TABLE 7. Variation of Conditional Probability That at Least $M$ Reactors Would be Contaminated Following an Accident at an HNEC With source and Plume Width. Contamination Defined by Normalized Air Concentration Greater Than $10^{-7} \mathrm{sm}^{-3}$ or Normalized Surface Concentration Greater than $10^{-9} \mathrm{~m}^{-2}$.

\begin{tabular}{ccccccccccc}
3 & 4 & 5 & 7 & 8 & 9 & 11 & 12 & 13 & 15 & 16 \\
\hline 1.000 & .878 & .397 & .158 & .127 & .081 & .066 & .059 & .056 & .018 & .018 \\
1.000 & .878 & .397 & .160 & .129 & .081 & .067 & .061 & .057 & .019 & .019 \\
1.000 & .886 & .492 & .259 & .203 & .153 & .096 & .066 & .066 & .027 & .022 \\
1.000 & .908 & .519 & .286 & .210 & .180 & .128 & .073 & .063 & .009 & \\
1.000 & .908 & .517 & .284 & .210 & .181 & .129 & .081 & .070 & .020 & .010 \\
1.000 & .906 & .522 & .295 & .228 & .200 & .136 & .082 & .071 & .021 & .011
\end{tabular}


Energy Center Configuration. The sensitivity of the results given in Tables 4 and 5 to the configuration chosen for the HNEC was examined by comparison with results of computations for 6 other configurations. In each case the average separation between adjacent clusters was set at $12.7 \mathrm{~km}$, the same as for the HNEC. The configurations selected were a circle, (all 5 clusters on the perimeter), a cross in which the clusters were arranged on perpendicular lines with 3 clusters each, and lines with different orientations. The HNEC configuration is nearly a line oriented NW/SE.

Table 8 shows the variation of the conditional probability with configuration. The effect of configuration on the maximum number of reactors contaminated following a release is immediately obvious. If the risks associated with the contamination of 3 or more clusters are excessive, a circular configuration can eliminate that probability. However, Table 8 shows that the probability of 2 reactor involvement is relatively high for a circular configuration when compared with the other configurations. Similar results are seen for the cross configuration.

When a linear configuration is used, the probability that all reactors would be involved following an accident will always exist. But, in general, linear configurations have relatively low probabilities of 2 cluster contamination. Comparison of the probabilities for $M \geq 7$ shows that variation of line orientation has a significant effect. Rotating line orientation $45^{\circ}$ from N/S to NW/SE increases the probability of 2 cluster involvement by a factor of 3 and 3 cluster involvement by almost a factor of 3 .

While the variations just discussed appear to be real, the basic model used in the computations combined with the climatological resolution of wind direction can lead to unreal variations. A small $\left(<10^{\circ}\right)$ reorientation of a configuration 
TABLE 8. Variation of Conditional Probability That at Least $M$ Reactors Would be Contaminated Following an

Accident at an HNEC with NEC Geometric Configuration. Contamination Defined by Normalized Air or Surface Concentration Greater than Zero.

\section{Configuration}

$\begin{array}{lllllllllllllll}\text { HNEC } & 1.000 & .884 & .427 & .194 & .165 & .121 & .108 & .100 & .090 & .030 & .030 & \\ \text { N/S Line } & 1.000 & .862 & .300 & .063 & .055 & .055 & .049 & .039 & .039 & .033 & .023 & .019 \\ \text { NW/SE Line } & 1.000 & .886 & .390 & .190 & .160 & .160 & .152 & .112 & .112 & .104 & .064 & .058 \\ \text { E/W Line } & 1.000 & .867 & .321 & .111 & .098 & .098 & .070 & .053 & .053 & .048 & .031 & .027 \\ \text { NE/SW Line } & 1.000 & .866 & .319 & .104 & .095 & .095 & .064 & .050 & .050 & .043 & .030 & .024 \\ \text { Cross } & 1.000 & .891 & .471 & .265 & .216 & .178 & .033 & .033 & & & \\ \text { Circle } & 1.000 & .881 & .406 & .236 & .183 & .091 & & & & & \end{array}$


with respect to prevailing wind directions may significantly alter the probabilities computed. And in some cases can alter the maximum number of clusters that could be involved following a accident. Reorientation of the HNEC by a few degrees (or changing the orientation of the sectors in which wind directions are reported) would increase the maximum number of reactors involved to 20 . These changes are artifacts that limit the utility of the results in a quantitative sense.

Cluster spacing. The conceptual HNEC is not typical of many energy centers because it is relatively widely dispersed. Therefore each of the seven cases was reevaluated with spacing between clusters reduced by a factor of 4. Reducing spacing by a factor of 4 reduces the distance from the virtual point source to the receptor without changing the distance between the virtual and real sources. This increases both the corrected air and surface concentrations by more than a factor of 4 . However, the resulting changes in probability are generally less than a factor of 2 .

Table 9 shows the conditional probability for a relatively high level of contamination for both close and wide spacing. Relatively small increases in probability are shown for 2 cluster involvement when the spacing is reduced. The increases in probability are relatively large for 3 and 4 cluster involvement.

For a more detailed examination of the effects of spacing Table 10, which gives results for the HNEC configuration with close spacing, can be compared with Table 4 . With close spacing the highest level of 2 cluster contamination occurs at $\bar{x} / \dot{Q}$. $\geq$ $4.64 \times 10^{-5} \mathrm{sm}^{-3}$, while for the standard HNEC it occurs at $\bar{X} / Q \geq 4.64 \times 10^{-6} \mathrm{sm}^{-3}$. In general, for a given $M$ and a fixed probability, the level of contamination is about an order of magnitude greater for the closely spaced HNEC that it is for the widely spaced center. 
TABLE 9. Variation of Conditional Probability That at Least M Reactors Would be Contaminated Following an Accident at an HNEC with Configuration and spacing Between Clusters. Contamination Defined by Normalized Air Concentration Equal to or Greater than $10^{-7} \mathrm{sm}^{-3}$ or Normalized Surface Concentration Equal to or Greater than $10^{-9} \mathrm{~m}^{-2}$.

Number of Reactors

\begin{tabular}{|c|c|c|c|c|c|c|c|c|c|c|c|c|c|}
\hline Configuration & Spacing & 3 & 4 & 5 & 7 & 8 & 9 & 11 & 12 & 13 & 15 & 16 & 20 \\
\hline HNEC & $\begin{array}{l}C \\
W\end{array}$ & $\begin{array}{l}1.000 \\
1.000\end{array}$ & $\begin{array}{l}.884 \\
.878\end{array}$ & $\begin{array}{l}.427 \\
.397\end{array}$ & $\begin{array}{l}.194 \\
.158\end{array}$ & $\begin{array}{l}.165 \\
.127\end{array}$ & $\begin{array}{l}.121 \\
.081\end{array}$ & $\begin{array}{l}.108 \\
.066\end{array}$ & $\begin{array}{l}.100 \\
.059\end{array}$ & $\begin{array}{l}.090 \\
.056\end{array}$ & $\begin{array}{l}.030 \\
.018\end{array}$ & $\begin{array}{l}.030 \\
.018\end{array}$ & \\
\hline $\mathrm{N} / \mathrm{S}$ Line & $\begin{array}{l}C \\
W\end{array}$ & $\begin{array}{l}1.000 \\
1.000\end{array}$ & $\begin{array}{l}.862 \\
.860\end{array}$ & $\begin{array}{l}.300 \\
.293\end{array}$ & $\begin{array}{l}.063 \\
.055\end{array}$ & $\begin{array}{l}.055 \\
.040\end{array}$ & $\begin{array}{l}.055 \\
.032\end{array}$ & $\begin{array}{l}.049 \\
.021\end{array}$ & $\begin{array}{l}.038 \\
.011\end{array}$ & $\begin{array}{l}.038 \\
.011\end{array}$ & $\begin{array}{l}.032 \\
.002\end{array}$ & $\begin{array}{l}.022 \\
.001\end{array}$ & .017 \\
\hline NW/SE Line & $\begin{array}{l}C \\
W\end{array}$ & $\begin{array}{l}1.000 \\
1.000\end{array}$ & $\begin{array}{l}.886 \\
.881\end{array}$ & $\begin{array}{l}.390 \\
.370\end{array}$ & $\begin{array}{l}.190 \\
.162\end{array}$ & $\begin{array}{l}.158 \\
.121\end{array}$ & $\begin{array}{l}.156 \\
.110\end{array}$ & $\begin{array}{l}.145 \\
.090\end{array}$ & $\begin{array}{l}.105 \\
.041\end{array}$ & $\begin{array}{l}.105 \\
.041\end{array}$ & $\begin{array}{l}.095 \\
.016\end{array}$ & $\begin{array}{l}.059 \\
.009\end{array}$ & .050 \\
\hline $\mathrm{E} / \mathrm{W}$ Line & $\begin{array}{l}\mathrm{C} \\
\mathrm{W}\end{array}$ & $\begin{array}{l}1.000 \\
1.000\end{array}$ & $\begin{array}{l}.870 \\
.865\end{array}$ & $\begin{array}{l}.340 \\
.314\end{array}$ & $\begin{array}{l}.130 \\
.102\end{array}$ & $\begin{array}{l}.098 \\
.081\end{array}$ & $\begin{array}{l}.097 \\
.075\end{array}$ & $\begin{array}{l}.068 \\
.042\end{array}$ & $\begin{array}{l}.052 \\
.018\end{array}$ & $\begin{array}{l}.052 \\
.018\end{array}$ & $\begin{array}{l}.046 \\
.005\end{array}$ & $\begin{array}{l}.029 \\
.005\end{array}$ & .025 \\
\hline NE/SW Line & $\begin{array}{l}C \\
W\end{array}$ & $\begin{array}{l}1.000 \\
1.000\end{array}$ & $\begin{array}{l}.866 \\
.862\end{array}$ & $\begin{array}{l}.319 \\
.304\end{array}$ & $\begin{array}{l}.104 \\
.081\end{array}$ & $\begin{array}{l}.093 \\
.062\end{array}$ & $\begin{array}{l}.092 \\
.056\end{array}$ & $\begin{array}{l}.059 \\
.024\end{array}$ & $\begin{array}{l}.046 \\
.012\end{array}$ & $\begin{array}{l}.046 \\
.012\end{array}$ & $\begin{array}{l}.038 \\
.002\end{array}$ & $\begin{array}{l}.026 \\
.001\end{array}$ & .020 \\
\hline Cross & $\begin{array}{l}C \\
W\end{array}$ & $\begin{array}{l}1.000 \\
1.000\end{array}$ & $\begin{array}{l}.891 \\
.885\end{array}$ & $\begin{array}{l}.471 \\
.433\end{array}$ & $\begin{array}{l}.265 \\
.216\end{array}$ & $\begin{array}{l}.216 \\
.173\end{array}$ & $\begin{array}{l}.178 \\
.137\end{array}$ & $\begin{array}{l}.033 \\
.019\end{array}$ & $\begin{array}{l}.033 \\
.019\end{array}$ & & & & \\
\hline Circle & $\begin{array}{l}\mathrm{C} \\
\mathrm{W}\end{array}$ & $\begin{array}{l}1.000 \\
1.000\end{array}$ & $\begin{array}{l}.881 \\
.877\end{array}$ & $\begin{array}{r}.428 \\
.386\end{array}$ & $\begin{array}{l}.258 \\
.206\end{array}$ & $\begin{array}{l}.205 \\
.159\end{array}$ & $\begin{array}{l}.091 \\
.082\end{array}$ & & & & & & \\
\hline
\end{tabular}


TABIE 10. Conditional Probability That at Least $M$ Reactors Would be Contaminated Following an Accident at an HNEC, Assuming Close Spacing. Contamination Defined by Normalized Air Concentration Equal to or Greater than Tabled Value.

\begin{tabular}{|c|c|c|c|c|c|c|c|c|c|c|}
\hline \multirow{2}{*}{$\begin{array}{l}\text { Nomalized } \\
\text { Contration }\end{array}$} & \multicolumn{10}{|c|}{ Number of Reactors } \\
\hline & 3 & 4 & 5 & 7 & 8 & 9 & 11 & 12 & 13 & 16 \\
\hline$\left(\sin ^{-3}\right)$ & & & & & & & & & & \\
\hline $1.00 \times 10^{-4}$ & 1.000 & .850 & .250 & & & & & & & \\
\hline $4.64 \times 10^{-5}$ & 1.000 & .852 & .257 & .009 & .005 & .005 & & & & \\
\hline $2.15 \times 10^{-5}$ & 1.000 & .853 & .268 & .021 & .012 & .008 & & & & \\
\hline $1.00 \times 10^{-5}$ & 1.000 & .853 & .285 & .040 & .024 & .014 & & & & \\
\hline $4.64 \times 10^{-6}$ & 1.000 & .861 & .313 & .070 & .038 & .019 & .004 & .004 & .004 & \\
\hline $2.15 \times 10^{-6}$ & 1.000 & .872 & .353 & .114 & .070 & .037 & .022 & .016 & .016 & \\
\hline $1.00 \times 10^{-6}$ & 1.000 & .880 & .398 & .163 & .129 & .075 & .061 & .052 & .052 & .018 \\
\hline $4.64 \times 10^{-7}$ & 1.000 & .881 & .414 & .179 & .148 & .103 & .090 & .082 & .074 & .024 \\
\hline $2.15 \times 10^{-7}$ & 1.000 & .884 & .420 & .187 & .155 & .112 & .099 & .090 & .080 & .026 \\
\hline $1.00 \times 10^{-7}$ & 1.000 & .884 & .427 & .194 & .165 & .117 & .104 & .095 & .084 & .028 \\
\hline$>0$ & 1.000 & .884 & .427 & .194 & .165 & .121 & .108 & .100 & .090 & .030 \\
\hline
\end{tabular}


Deposition Velocity. The deposition velocity is the last of the model parameters evaluated in the model sensitivity studies. Equation (7) indicates that the corrected air concentration decreases as the deposition velocity increases. The variation of surface deposition is more complex as shown in Equation (8). Differentiation of Equation (8) with respect to deposition velocity indicates that surface concentration is maximized for some value of deposition velocity. The deposition velocity that maximizes surface concentration is a function of wind speed, atmospheric stability, and the distances of the real source and receptor from the virtual point source.

Figures 3 and 4 show the effect of deposition velocity on the conditional probability with contamination defined by air concentration. Figure 3 is for $M \geq 7$, while Figure 4 is for $M \geq 11$. Both figures show that small deposition velocities have little effect on air concentrations over the range of distances in the HNEC. They also show that increasing deposition velocity has more effect at high levels of contamination than at low levels. Both of these results are expected.

Comparison of the figures shows that the reduction of probability at large deposition velocities occurs more gradually for $M \geq 7$ than it does for $M \geq 11$. This can be explained as a result of the summation over all possible combinations of sources, receptors and atmospheric conditions. Since more source-receptor combinations lead to $M \geq 7$ than lead to $M \geq 11$, the variation of probability with $V_{d}$ should be more gradual for $M \geq 7$ as shown.

As a practical matter, for $\bar{x} / Q \geq 10^{-7} \mathrm{sm}^{-3}$ or less, air concentrations computed with $\mathrm{v}_{\mathrm{d}} \geq .01 \mathrm{~ms}^{-1}$ can be assumed to be equal to those for non-depositing material.

The variation of conditional probability with deposition velocity when contamination is defined by surface concentration is shown in Figures 5 and 6 for $M \geq 7$ and $M \geq 11$ respectively. 


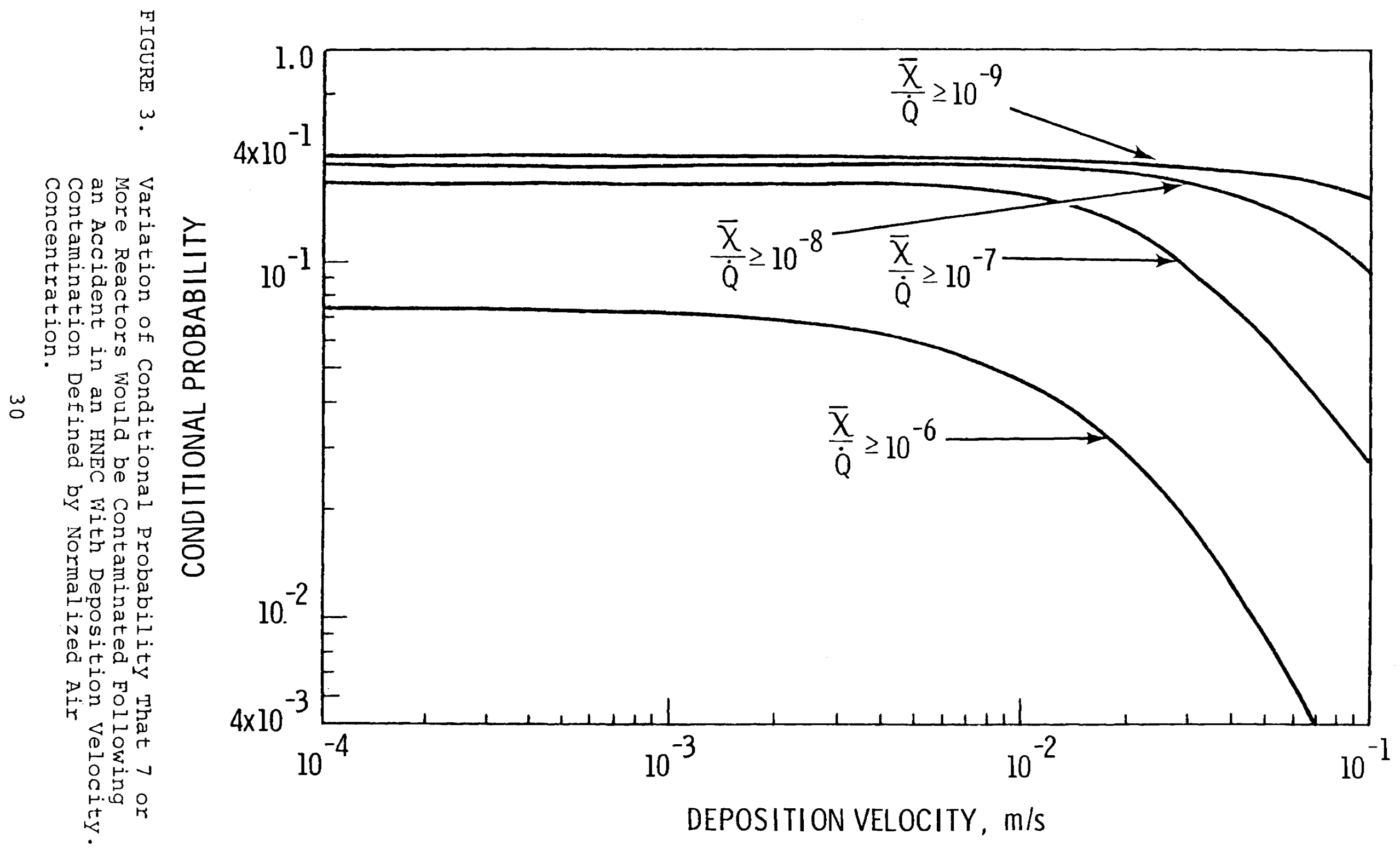




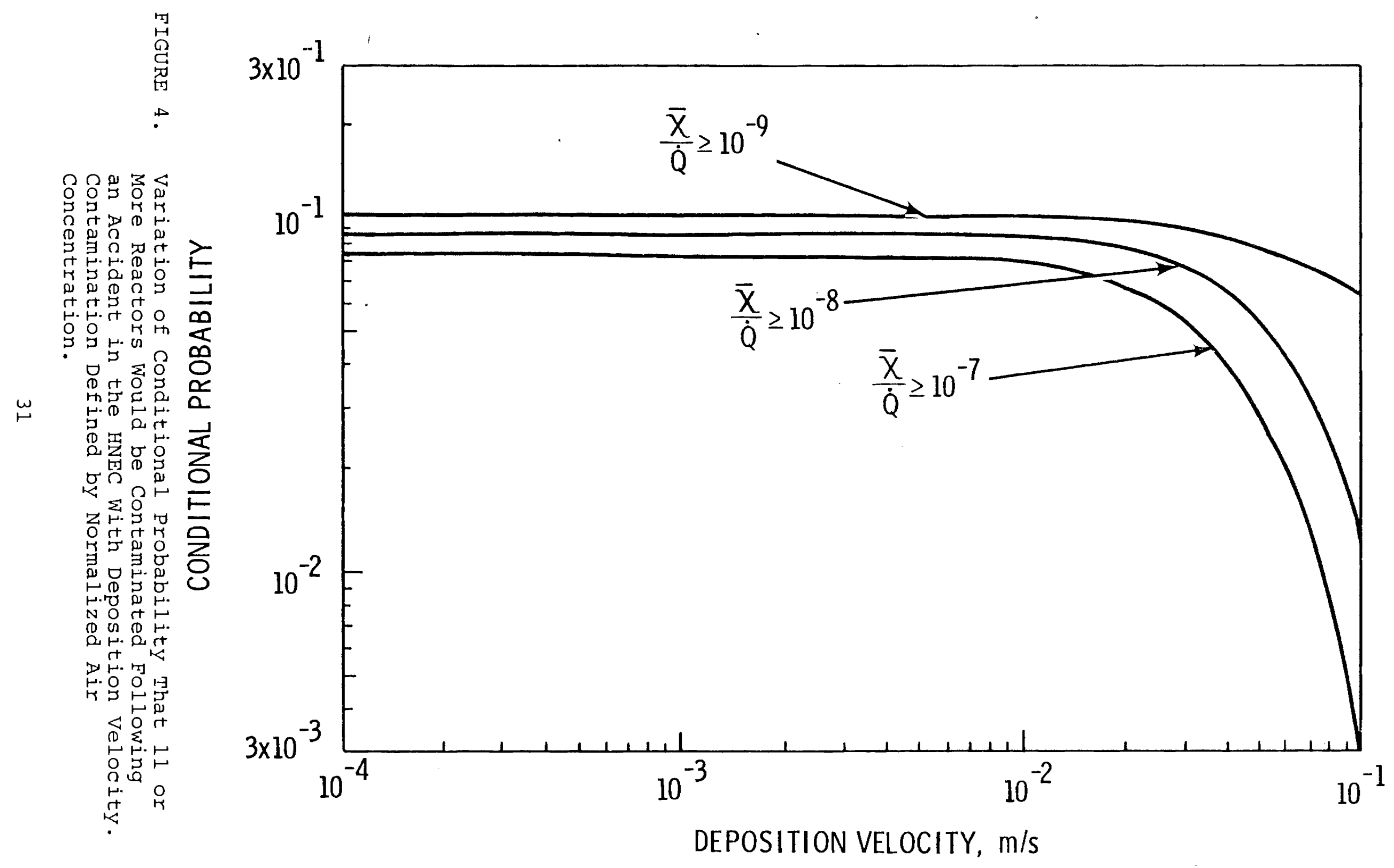




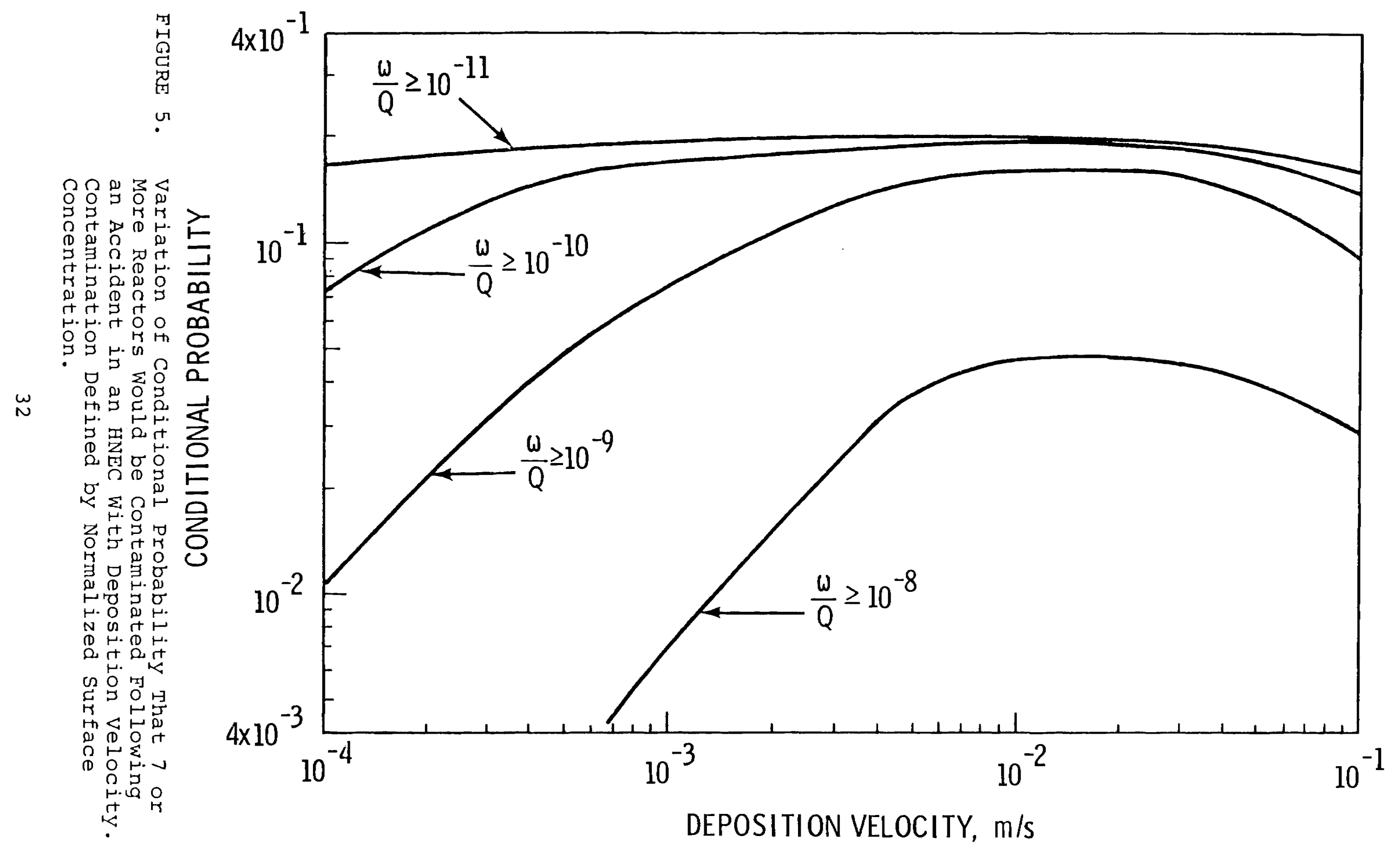




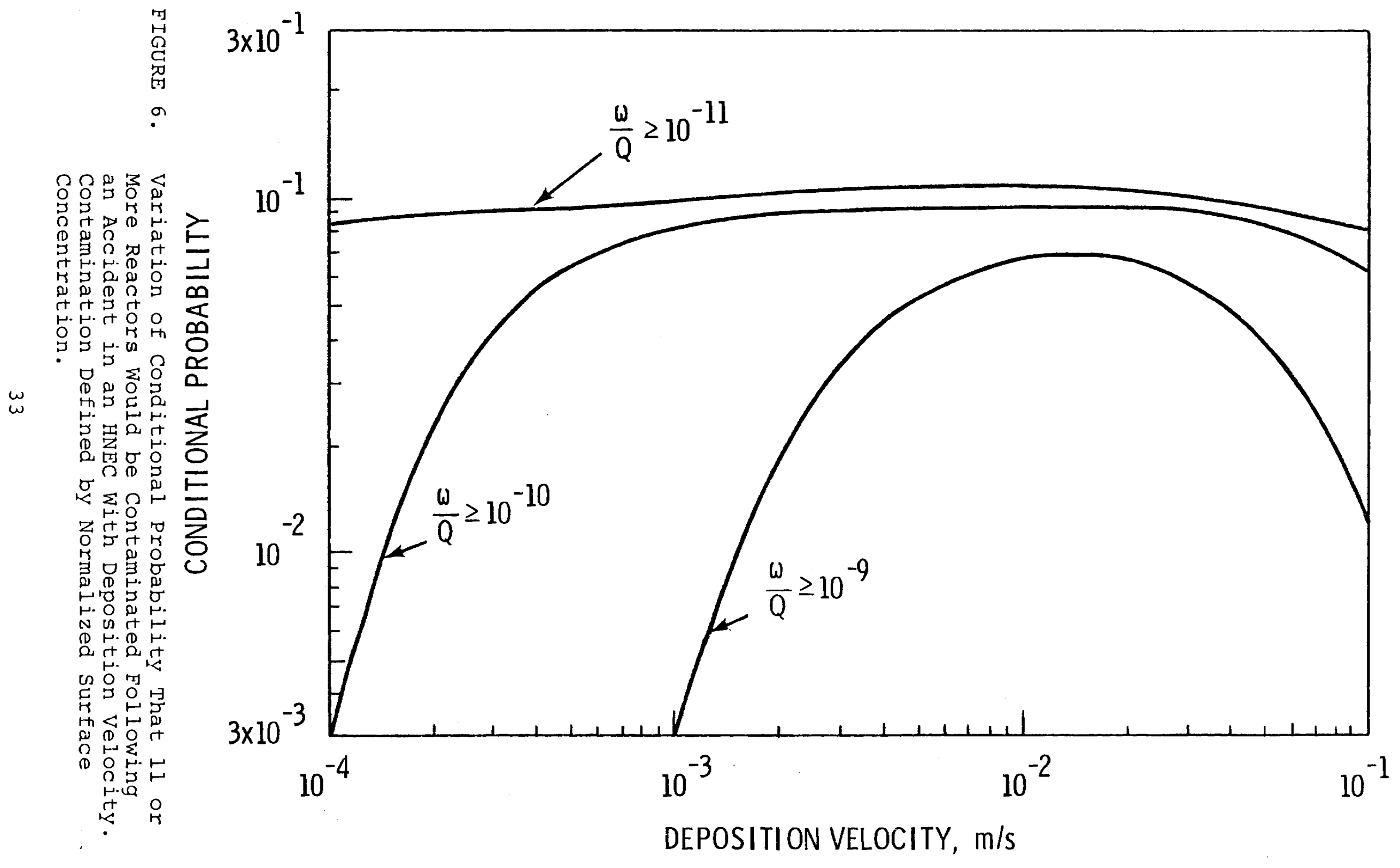


These figures show the general trend that would be expected on the basis of the discussion of Equation (8). Again the effects of $\mathrm{V}_{\mathrm{d}}$ are most pronounced for the nighest level of involvements, and they are more gradual for $M \geq 7$ than for $M \geq 11$.

The predicted maximum in surface concentration is reflected in the broad peaks in probability in Figures 5 and 6 . These peaks occur at deposition velocities of about $.01 \mathrm{~ms}^{-1}$.

\section{CONCIUSIONS}

As part of the conceptual evaluation of a Hanford Nuclear Energy Center, the reliability of generation is being assessed. The purpose of the work discussed in this report was to provide meteorological estimates of the probability of multiple reactor contamination following an accidental release of radioactivity. In this context the primary results of the study are contained in Tables 4 and 5 . This section summarizes the results in these tables and in the section on model sensitivity.

The conditional probability that contamination would be confined to the reactors in a single cluster in the HNEC is .806 if it is assumed that an accident will occur. The probability that reactors in two or more clusters would be contaminated is .194, that for three of more is .108, and that for four or more is .030.

If contamination is further defined by normalized air or surface concentrations at downwind reactors, the probability that two or more clusters would be involved at a relatively high level (normalized air concentration $\geq 10^{-7} \mathrm{sm}^{-3}$ or surface concentration $\geq 10^{-9} \mathrm{~m}^{-2}$ ) is .158 . The probability that three or more clusters being contaminated at these levels is .066. Thus, the probability for two or more clusters being involved is about 3 times the probability that a given reactor will be the source of the release, and the probability of 
three or more clusters being involved is somewhat larger than the probability of a given reactor having the accidental release.

Sensitivity studies indicate that the probability estimates presented in Tables 4 and 5 can be altered significantly by changing several of the model parameters. However, the model, as applied to the HNEC, is not sensitive to increases in the thickness of the atmosphere's mixing layer when the layer thickness is greater than $500 \mathrm{~m}$.

Increasing the assumed width of the source from 100 to $400 \mathrm{~m}$ has no effect on the probability that $M$ or more reactors would be downwind of the accident. But, it did increase the level of contamination slightly by decreasing the plume depletion due to deposition near the source. A further increase in source width to $1600 \mathrm{~m}$ increases probabilities close to the source (small M) by increasing the plume coverage and increases probabilities at a distance (large M) by decreasing deposition.

Increasing plume widths from 22.5 to 45 degrees decreases concentrations and increases plume coverage. The net result is increases in conditional probability of up to .128 and .047 for 100 and $1600 \mathrm{~m}$ source widths respectively when a relatively high level of contamination is considered.

Changing the energy center configuration can have a significant affect on the probability of multiple reactor contamination. Variations in the conditional probability of factors of 3 and more can be obtained by changing the configuration and its orientation with respect to the prevailing wind directions. In using configuration changes to alter the conditional probability, trade offs are required. Reduction in the probability of involvement of two or more clusters may increase the probability of involving 3 or 4 clusters. 
Decreasing the spacing between clusters increases the level of contamination significantly, if the number of reactors and probability are predetermined. However, there are only small increases in the probability of contamination at a given level and number of reactors when spacing is decreased.

Finally, the model results are sensitive to the choice of deposition velocities. Deposition velocities above $.01 \mathrm{~ms}^{-1}$ decrease air concentrations significantly, and this is reflected in a decrease in conditional probabilities. They also affect the amount of material deposited. The probability of involvement, where involvement is defined by surface concentration, is a maximum for the HNEC for deposition velocities of about $.01 \mathrm{~ms}^{-1}$. As a result, the use of a deposition velocity of $.01 \mathrm{~ms}^{-1}$, which is consistent with observed values for reactor effluents of interest, yields conservative predictions of contamination through both air and surface concentrations.

In the light of the results of the model sensitivity studies, the estimates of the conditional probability that $M$ or more reactors would be contaminated following a release of radioactivity at an HNEC presented in Tables 4 and 5 are considered to be reasonable. Although the estimates can be altered by changing meteorological parameters in the models, there are no compelling reasons to change them, nor are there significant benefits to be gained if the parameters are changed. Energy center configuration and spacing are the only reasonable means for use in altering the conditional probability of multiple reactor contamination following a release of radioactive material. 
Appendix A

Reactor Accident Classes 


\section{TABLE Al. Classification of Postulated Accidents and Occurrences*}

\begin{tabular}{|c|c|c|}
\hline Class & Description & Example (s) \\
\hline 1 & Trivial incidents & $\begin{array}{l}\text { Small spills } \\
\text { Small leaks inside } \\
\text { containment }\end{array}$ \\
\hline 2 & $\begin{array}{l}\text { Misc. small releases } \\
\text { outside containment }\end{array}$ & $\begin{array}{l}\text { Spills } \\
\text { Leaks and pipe breaks }\end{array}$ \\
\hline 3 & $\begin{array}{l}\text { Radwaste system } \\
\text { failures }\end{array}$ & $\begin{array}{l}\text { Equipment failure } \\
\text { Serious malfunction or } \\
\text { human error }\end{array}$ \\
\hline 4 & $\begin{array}{l}\text { Events that release } \\
\text { radioactivity into } \\
\text { the primary system }\end{array}$ & $\begin{array}{l}\text { Fuel defects during } \\
\text { normal operation } \\
\text { Transients outside } \\
\text { expected range of } \\
\text { variables }\end{array}$ \\
\hline 5 & $\begin{array}{l}\text { Events that release } \\
\text { radioactivity into } \\
\text { secondary system }\end{array}$ & $\begin{array}{l}\text { Class } 4 \text { and Heat } \\
\text { Exchanger Leak }\end{array}$ \\
\hline 6 & $\begin{array}{l}\text { Refueling accidents } \\
\text { inside containment }\end{array}$ & $\begin{array}{l}\text { Drop fuel element } \\
\text { Drop heavy object onto } \\
\text { fuel } \\
\text { Mechanical malfunction } \\
\text { of loss of cooling in } \\
\text { transfer tube }\end{array}$ \\
\hline 7 & $\begin{array}{l}\text { Accidents to spent } \\
\text { fuel outside contain- } \\
\text { ment }\end{array}$ & $\begin{array}{l}\text { Drop fuel element } \\
\text { Drop heavy object onto } \\
\text { fuel } \\
\text { Drop shielding cask - } \\
\text { loss of cooling to cask, } \\
\text { transportation incident } \\
\text { on site }\end{array}$ \\
\hline 8 & $\begin{array}{l}\text { Accident initiation } \\
\text { considered in design- } \\
\text { basis } \\
\text { Evaluation in the } \\
\text { safety analysis report }\end{array}$ & $\begin{array}{l}\text { Reactivity transient } \\
\text { Rupture of primary } \\
\text { piping } \\
\text { Flow decrease - steam- } \\
\text { line break }\end{array}$ \\
\hline 9 & $\begin{array}{l}\text { Hypothetical sequences } \\
\text { of failures } \\
\text { More severe than } \\
\text { Class } 8\end{array}$ & $\begin{array}{l}\text { Successive failures of } \\
\text { multiple barriers } \\
\text { normally provided and } \\
\text { maintained }\end{array}$ \\
\hline
\end{tabular}


Appendix B

Accidents Involving Reactor Cores 
TABLE Bl. Release Categories Following Reactor Accidents Involving Core*

Pressurized Water Reactors

PWR 1 Steam explosion due to molten $\mathrm{UO}_{2}$ falling into water followed by missile rupturing containment.

PWR 2 Core melt and failure of radioactivity removal systems followed by rupture of containment.

PWR 3 Similar to PWR 1 and 2 but involves partial success of radioactivity removal systems.

PWR 4 Core melt with containment not fully isolated, containment radioactivity removal systems have failed.

PWR 5 Similar to PWR 4 except removal systems operative.

PWR 6 Core melt through bottom, above ground containment intact. Radioactivity removal systems inoperative.

PWR 7 Similar to PWR 6 except radioactivity removal system operating.

PWR 8 Core doesn't melt, release of activity in the gaps of fuel rods, containment fails to isolate properly.

PWR 9 Similar to PWR 8, except containment isolates correctly.

\section{Boiling Water Reactors}

BWR 1 Similar to PWR 1.

BWR 2 Core melt after containment over pressure rupture caused by loss of decay heat removal systems, limited deposition of radioactive materials. Release directly to atmosphere.

BWR 3 Similar to BWR 2 except material released through the reactor building to the atmosphere.

BWR 4 Core melt, containment fails to operate properly and the leakage is enough to prevent containment over pressure rupture.

BWR 5 Core does not melt, but activity is released from the gap of the fuel rods. Activity passes through reactor building gas treatment system and is released to the atmosphere through a tall stack.

* From Reference 11 
TABLE B2. Parameters of Releases Following Reactor Accidents Involving Core*

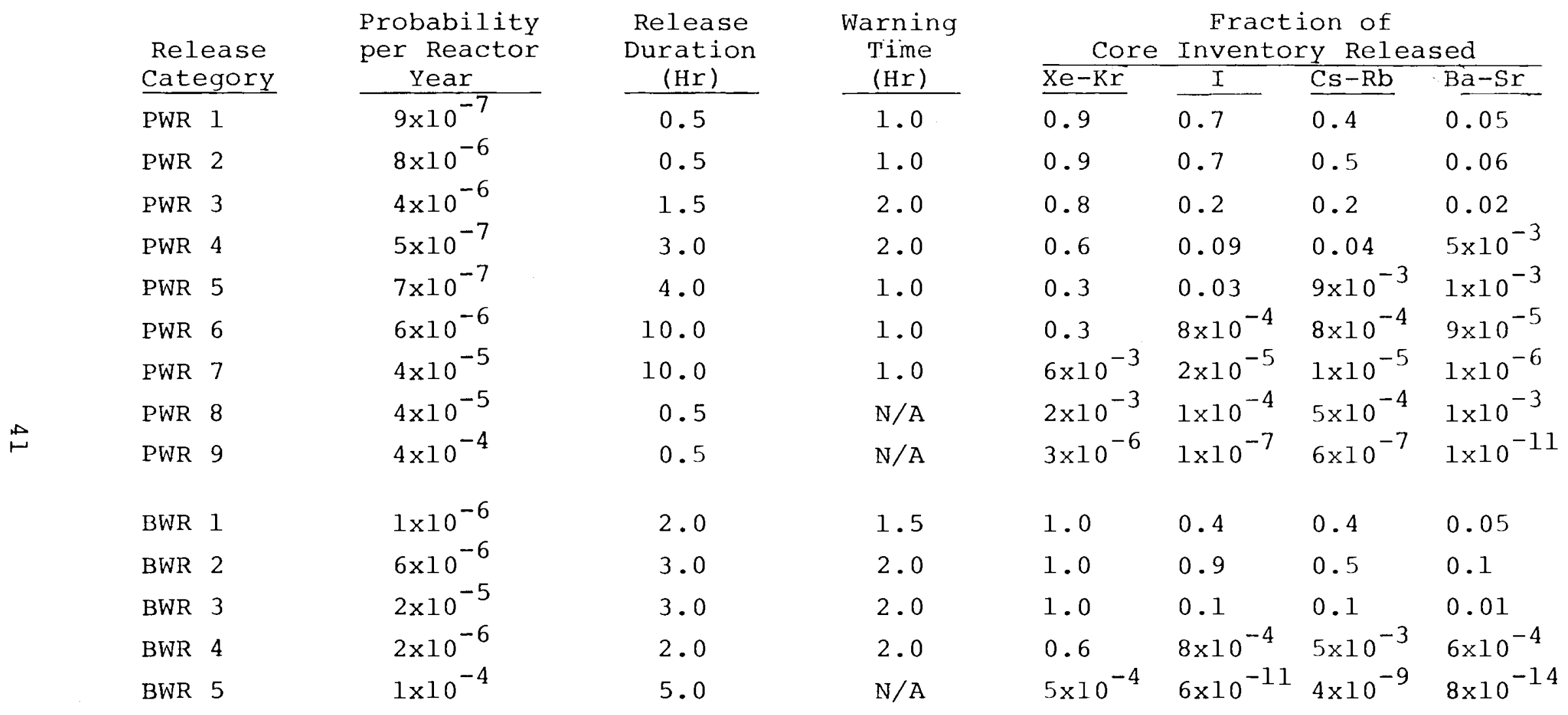

\footnotetext{
From Reference 11 , Table 5.1
} 


\section{REFERENCES}

1. The Hanford Nuclear Energy Center A Preliminary Conceptual Study, BNWL-B-332, Battelle, Pacific Northwest Laboratories, Richland, WA, January 1974, $316 \mathrm{p}$.

2. The Hanford Nuclear Energy Center An Interim Conceptual Study, BNTL-B-458, Battelle, Pacific Northwest Laboratories, Richland, WA, October 1975, $66 \mathrm{p}$.

3. The Hanford Nuclear Energy Center An Interim Conceptual Study, BNiL-B-458 II, Battelle, Pacific Northwest Laboratories, Richland, WA, November 1976, 51 p.

4. Electric Power Transmission for a Hanford Nuclear Energy Center, BNWL-B-426, Battelle, Pacific Northwest Laboratories, Richland, WA, September 1975, 69 p.

5. Status Report - Conceptual Fuel Cycle studies for the Hanford Nuclear Energy Center, BNWL-B-437, Battelle, Pacific Northwest Laboratories, Richland, WA, November $1975,41 \mathrm{p}$.

6. Heat Sink Management for a Hanford Nuclear Energy Center, BNWL-B-448, Battelle, Pacific Northwest Laboratories, Richland, WA, November 1975, $51 \mathrm{p}$.

7. Young, J. R., I. D. Kannberg, J. V. Ramsdell, W. H. Richard and D. G. Watson, Selection of Head Disposal Methods for a Hanford Nuclear Energy Center, BNWL-2003, Battelle, Pacific Northwest Laboratories, Richland, WA, June 1976, $97 \mathrm{p}$.

8. Ramsdell, J. V., Impact of a Hanford Nuclear Energy Center on Ground Level Foq and Humidity, BNwL-2058, Battelle, Pacific Northwest Laboratories, Richland, WA, March 1977 , $107 \mathrm{p}$.

9. Clark, R. G. and W. J. Dowis, Reliability of Generation at a Hanford Nuclear Energy Center (HNEC), BNWL-2474, Battelle, Pacific Northwest Laboratories, Richland, WA, 1978.

10. The Safety of Nuclear Power Reactors (Iight Water-Cooled) and Related Facilities, WASH-1250, U.S. Atomic Energy Commission, 1973 .

11. Reactor Safety Study, WASH-1400 (NUREG 75/014), U.S. Nuclear Regulatory Commission, October 1975. 
12. Gifford, F. A., "An Outline of Theories of Diffusion in the Lower Layers of the Atmosphere," in Meteorology and Atomic Energy-1968, D. Slade, ed., TID-24 $\overline{190, \text { U.S. Atomic }}$ Energy Commission, July 1968.

13. Csanady, G. T., "Turbulent Diffusion in the Environment," D. Reidell, Boston, 248 P., 1973.

14. Van der Hoven, I., "Deposition of Particles and Gases," in Meteorology and Atomic Energy-1968, D. Slade, ed., TID-24190, U.S. Atomic Energy Commission, July 1968 .

15. Horst, T. W., "A Surface Depletion Model for Deposition From a Gaussian Plume," Atmosphere-Surface Exchange of Particulate and Gaseous Pollutants, CONF 74092I, ERDA Symposium Series 38, U.S. Energy Research and Development Administration, 1976, pp. 423-433.

16. Stone, W. A., D. F. Jenne and J. M. Thorp, Climatography of the Hanford Area, BNWL-1605, Battelle, pacific Northwest Laboratories, Richland, WA, 1972.

17. Briggs, G. A., "Diffusion Estimation for Small Emissions," Atmospheric Turbulence and Diffusion Laboratory 1973 Annual Report, ATDL-106, December 1974, pp. 83-145.

18. "Onsite Meteorological Programs," Regulatory Guide 1.23, U.S. Nuclear Regulatory Commission, February 1972.

19. "Methods for Estimating Atmospheric Transport and Dispersion of Gaseous Effluents in Routine Releases from Light-Water-Cooled Reactors," Regulatory Guide 1.III, U.S. Nuclear Regulatory Commission, March 1976.

20. Sehmel, G. A. and W. H. Hodgson, "Predicted Dry Deposition Velocities," Atmosphere-Surface Exchange of Particulate and Gaseous Pollutants," CONF 740921, ERDA Symposium Series 38, U.S. Energy Research and Development Administration, 1976, pp. 399-422.

21. Heinemann, K., K. J. Vogt, and L. Angeletti, "Deposition and Biological Half-Life of Elemental Iodine on Grass and Clover," Atmosphere-Surface Exchange of Particulate and Gaseous pollutants," CONF 740921, ERDA Symposium Series 38, U.S. Energy Research and Development Administration, 1976, pp. 136-152. 
No. of Copies

OFFSITE

1

1

1

1

1 1300 Hoge Building
seattle, WA 98104

Gordon Culp

1

Electric Power Research Institute Post Office Box 10412

Palo Alto, CA 94304

Laura Henning

20 Department of Energy

Mail stop F-309

Washington, DC 20545

W. F, Savage, Chief

Advanced Concepts Evaluation Branch 
No. of

Copies

OFFSITE

DOE Technical Information Center

1 Nuclear Regulatory Commission

Washington, DC 20555

1

Pacific Northwest Utilities Conference

Committee

Post Office Box 1231

Wenatchee, WA 98801

Howard C. Elmore, Chairman

1 Pacific Northwest Utilities Conference Committee on Engineering and Planning

2730 Northwest 77 th Place

Portland, OR 97213

David J. Lewis, Consultant

1 Portland General Electric Company

621 Southwest Alder street

Portland, OR 97205

A. J. Porter, Vice President

1

Puget Sound Power and Light Company

Puget Power Building

Post office Box 535

Bellevue, WA 98004

John W. Ellis, President

1 Jack Criswell, General Manager

Springfield Utility Board

250 North "A" Street, Box 300

springfield, OR 97477

1 National Academy of Public Administration

1225 Connecticut Avenue NW

Washington, DC 20036

R. Kloman

1 Washington State Energy Office

1000 South Cherry

Olympis, WA 98504

Larry Bradley 
No. of

Copies

OFFSITE

15

ONSITE

DOE Richland Operations Office

O. J. Elgert

P. W. Gottschalk

R. H. Lindsey/G. L. Liffick

H. E. Ransom

F. R. Standerfer

M. W. Tiernan

Research and Development Programs Division

W. A. Burns (2)

40

Battelle-Northwest

D. B. Cearlock

R. L. Conley

D. W. Dragnich

R. F. Foster

J. J. Fuquay

H. Harty (10)

J. V. Ramsdell (10)

A. E. Reisenauer

W. H. Rickard

C. L. Simpson

J. K. Soldat

R. W. Wallace

D. G. Watson

Technical Information (5)

Technical Publications (3)
Washington Public Power Supply System

Rodger K. Woodruff

J. R. Young 
